\title{
Use of the lung ultrasound score in monitoring COVID-19 patients: it's time for a reappraisal
}

Luigi Vetrugno ${ }^{1,2^{*}} \mathbb{C}$, Daniele Orso ${ }^{1}$, Cristian Deana ${ }^{2}$, Flavio Bassi ${ }^{2}$, Gianmaria Cammarota ${ }^{3}$ and Tiziana Bove ${ }^{1,2}$

To the Editor,

The lung ultrasound score (LUS) - as far as the literature reports-provides an overall rating of pulmonary aeration loss through the examination of 12 specified thoracic regions [1]. The level of aeration loss of each examined region is rated from 0 (absence of B lines) to 3 (lung consolidation), and the sum of these ratings constitutes the overall LUS, which can thus range from a minimum of zero to a maximum of 36 [1]. In non-COVID-19 patients with acute respiratory distress syndrome (ARDS), the LUS correlates with disease severity and mortality [1]. In COVID-19-related ARDS, a number of studies have assessed the role of the LUS in severity prediction and monitoring the response to treatment. Lung ultrasound is a quick- and easy-to-learn medical technique, rendering the LUS an easily accessible tool. The median time required for an expert operator to obtain a LUS is just $5 \mathrm{~min}$. Ji and collaborators investigated the validity of using the LUS as a tool for monitoring the clinical progress of 280 COVID-19 patients [2]. The study confirmed their modified LUS (which generated an overall LUS scale of 0-60 by incorporating a score for pleural abnormalities [scale 0-2] for each of the 12 regions) to offer high prognostic accuracy (sensitivity and specificity both $>90 \%$ ). Here, the authors proposed a cutoff value $>12$ to predict an adverse outcome. Lichter et al., on the other hand, in their study of critically ill COVID-19 patients report an

*Correspondence: luigi.vetrugno@uniud.it

${ }^{1}$ Department of Medicine, University of Udine, via Colugna $n^{\circ} 50$, 33100 Udine, Italy

Full list of author information is available at the end of the article optimal cutoff value of 18 on the $0-36$ scale for predicting adverse outcome, with a reported sensitivity of $62 \%$ and a specificity of $75 \%$ [3], whereas Zhu et al. report a sensitivity of $81 \%$ and a specificity of $96 \%$ with a cutoff value of 7 [4]. However, the study by Ji et al. [2] is difficult to compare with other studies in the literature for the following two reasons: first, they used a modified LUS scale (note a recent international expert consensus on the use of multi-organ point-of-care LU in COVID-19 adopts the scale range of 0-36 [5] and does not consider the pleural line artifact); second, the patients in the study by Ji et al. appear less critically ill than those in other studies, as evidenced by the fact that $88 \%$ of patients had an average value of $\mathrm{PaO}_{2} / \mathrm{FiO}_{2}$ greater than $300 \mathrm{mmHg}$.

\section{Acknowledgements}

None.

Authors' contributions

All authors contributed equally to the manuscript. All authors read and approved the final manuscript.

Funding

None.

\section{Availability of data and materials}

Not applicable.

Ethics approval and consent to participate

Not applicable.

Consent for publication

Not applicable.

Competing interests

None for any authors. original author(s) and the source, provide a link to the Creative Commons licence, and indicate if changes were made. The images or other third party material in this article are included in the article's Creative Commons licence, unless indicated otherwise in a credit line to the material. If material is not included in the article's Creative Commons licence and your intended use is not permitted by statutory regulation or exceeds the permitted use, you will need to obtain permission directly from the copyright holder. To view a copy of this licence, visit http://creativecommons.org/licenses/by/4.0/. The Creative Commons Public Domain Dedication waiver (http://creativeco mmons.org/publicdomain/zero/1.0/) applies to the data made available in this article, unless otherwise stated in a credit line to the data. 


\section{Author details}

1 Department of Medicine, University of Udine, via Colugna n ${ }^{\circ} 50$,

33100 Udine, Italy. ${ }^{2}$ Anesthesia and Intensive Care Medicine Department,

ASUFC University-Hospital of Central Friuli, ASUFC, P.le S. Maria della Misericordia $\mathrm{n}^{\circ}$ 15, 33100 Udine, Italy. ${ }^{3}$ Department of Medicine and Surgery, University of Perugia, Perugia, Italy.

Received: 14 January 2021 Accepted: 27 January 2021

Published online: 03 February 2021

\section{References}

1. Bouhemad B, Mongodi S, Via G, Rouquette I. Ultrasound for "lung monitoring" of ventilated patients. Anesthesiology. 2015;122(2):437-47. https ://doi.org/10.1097/ALN.00000000000000558.

2. Ji L, Cao C, Gao Y, Zhang W, Xie Y, Duan Y, et al. Prognostic value of bedside lung ultrasound score in patients with COVID-19. Crit Care. 2020;24(1):700. https://doi.org/10.1186/s13054-020-03416-1.
3. Lichter Y, Topilsky Y, Taieb P, Banai A, Hochstadt A, Merdler I, et al. Lung ultrasound predicts clinical course and outcomes in COVID-19 patients. Intensive Care Med. 2020;46(10):1873-83. https://doi.org/10.1007/s0013 4-020-06212-1.

4. Zhu F, Zhao X, Wang T, Wang Z, Guo F, Xue X, et al. Ultrasonic characteristics and severity assessment of lung ultrasound in COVID-19 Pneumonia in Wuhan, China: a retrospective, observational study. Engineering (Beijing). 2020. https://doi.org/10.1016/j.eng.2020.09.007.

5. Hussain A, Via G, Melniker L, Goffi A, Tavazzi G, Neri L, et al. Multi-organ point-of-care ultrasound for COVID-19 (PoCUS4COVID): international expert consensus. Crit Care. 2020;24(1):702. https://doi.org/10.1186/s1305 4-020-03369-5.

\section{Publisher's Note}

Springer Nature remains neutral with regard to jurisdictional claims in published maps and institutional affiliations.
Ready to submit your research? Choose BMC and benefit from:

- fast, convenient online submission

- thorough peer review by experienced researchers in your field

- rapid publication on acceptance

- support for research data, including large and complex data types

- gold Open Access which fosters wider collaboration and increased citations

- maximum visibility for your research: over $100 \mathrm{M}$ website views per year

At BMC, research is always in progress.

Learn more biomedcentral.com/submissions 